\title{
High-altitude migration of Heteroptera in Britain
}

\author{
DON R. REYNOLDS ${ }^{1,2}$, BERNARD S. NAU ${ }^{3}$ and JASON W. CHAPMAN ${ }^{2,4}$ \\ ${ }^{1}$ Natural Resources Institute, University of Greenwich, Chatham, Kent ME4 4TB, UK; e-mail: D.Reynolds@greenwich.ac.uk \\ ${ }^{2}$ Rothamsted Research, Harpenden, Hertfordshire AL5 2JQ, UK \\ ${ }^{3} 15$ Park Hill, Toddington, Bedfordshire LU5 6AW, UK \\ ${ }^{4}$ Environment and Sustainability Institute, University of Exeter, Penryn, Cornwall TR10 9EZ, UK
}

Key words. Heteropteran bugs, aerial sampling, windborne migration, atmospheric transport, life-history strategies, seasonal cycles

\begin{abstract}
Heteroptera caught during day and night sampling at a height of $200 \mathrm{~m}$ above ground at Cardington, Bedfordshire, UK, during eight summers $(1999,2000$, and 2002-2007) were compared to high-altitude catches made over the UK and North Sea from the $1930 \mathrm{~s}$ to the 1950s. The height of these captures indicates that individuals were engaged in windborne migration over distances of at least several kilometres and probably tens of kilometres. This conclusion is generally supported by what is known of the species' ecologies, which reflect the view that the level of dispersiveness is associated with the exploitation of temporary habitats or resources. The seasonal timing of the heteropteran migrations is interpreted in terms of the breeding/overwintering cycles of the species concerned.
\end{abstract}

\section{INTRODUCTION}

Migratory propensity is highly variable in the Heteroptera: wing polymorphisms or polyphenisms are common in many species, and as a result some individuals lack fully-developed wings or flight muscles, or flight is limited by physiological/behavioural parameters (e.g. Zera \& Denno, 1997; Andersen, 2000; Socha et al., 2005; Socha \& Šla, 2006). Even in species or morphs which are fully flight-capable, and where there is a distinct migratory (as opposed to "station-keeping") flight phase, the actual migration range may be quite short - for example, a few hundred metres to a few kilometres in the Swedish metapopulations of Lygaeus equestris (Lygaeidae) (Solbreck, 1985; Solbreck \& Sillén-Tullberg, 1990). Migrations over longer distances may be exemplified by the invasive coreid bug Leptoglossus occidentalis which is expanding its range in North America and in Europe; while some of the spread is by means of timber shipments, the numerous adults caught in light traps along the south coast of England in 2008 clearly points to active flights across the English Channel (Malumphy et al., 2008). In "sunn pest" - several species of Eurygaster (Scutelleridae) and Aelia (Pentatomidae) in West Asia - there are to-and-fro migrations ranging from a few tens of kilometres up to $\sim 200$ $\mathrm{km}$ between mountain aestivation/hibernating sites and breeding areas in the plains (Johnson, 1969, p. $430 \mathrm{ff}$ ). There is some controversy as to the contribution of the wind as opposed to self-propelled flight in determining the migrant's track during these movements, although Brown (1965) found that flight direction was determined principally by the wind. Further examples of long-range seasonal migrations on the wind are those of Dysdercus spp. (Pyrrhocoridae), e.g. Dysdercus voelkeri in West Africa (Duviard, 1977); the windborne migration of the Rutherglen bug, Nysius vinitor (Lygaeidae) over distances of $200-300 \mathrm{~km}$ in eastern Australia (McDonald \& Farrow, 1988); and the huge numbers of Cyrtorhinus lividipennis (Miridae) and Microvelia spp. (Veliidae) found migrating at altitude in southeast and south Asia (Riley et al., 1987; Reynolds et al., 1999). Incidental catches of Heteroptera high in the air or over the ocean vast distances from land (e.g. Glick, 1939, 1957; Gressitt et al., 1961; Johnson, 1969, p. 429; Kerzhner, 1983; Wheeler, 2001, pp. 46-47) clearly indicate very long windborne movements.

Apart from studies primarily aimed at the management of migratory pests (e.g. sunn pest, Dysdercus, Nysius vinitor) the Heteroptera have featured in fundamental evolutionary/ecological studies. Among the betterstudied heteropteran species is Oncopeltus fasciatus (Lygaeidae) whose migration syndromes have been extensively investigated by Dingle and colleagues (Dingle, 2001). Movement abilities vary greatly in $O$. fasciatus, but some populations are highly migratory and successive generations invade northern states of the USA (such as Iowa and Michigan) in summer by wind-assisted movements from overwintering areas in the southern Atlantic and Gulf coast states (e.g. Dingle, 1982, 1991). In autumn, short day-length leads to adult reproductive diapause and promotes extensive migratory flight which, in turn, permits descendants of the original immigrants to escape to the south (Dingle, 1974).

The extreme wing-dimorphism found in many species of Heteroptera is conducive to investigations of the fitness costs associated with flight capabilities, in particular trade-offs between flight, reproduction and other lifehistory traits (see reviews in Dingle, 1996 and Zera \& Denno, 1997; Andersen, 2000). The benefits of allocating resources to early reproduction rather than flight may result in polymorphisms whereby only some of the indi- 
viduals in a given generation are able to undertake migratory movements, and in some cases flight capabilities may be lost completely. In addition, comparisons of the relative abundance of certain Heteroptera species in the "upper air" compared to that in collections at ground level, has supported some important concepts in modern ecology, namely the relationships between life-history features and temporal/spatial scales of habitat heterogeneity (Southwood, 1988a, and 2004 pers. com.). Recognition that the likelihood of migration was associated with the occupancy of temporary habitats (Southwood, 1962) was later extended to the view that suites of evolved lifehistory characteristics are shaped by adaptation to the habitat "templet" (Southwood, 1977, 1988b).

The Heteroptera of Northwest Europe are taxonomically well-known, and there have been many groundbased trapping studies (using light-traps and other "attractant" methods, and suction traps). The use of such techniques, however, often makes it difficult to distinguish foraging or very short-range dispersal flights from the longer-range migrations, and as a consequence the predisposition of macropterous individuals to make windborne movements at altitude is poorly understood. From both ecological and applied perspectives, it is important to know which species undertake these long-range movements, and why. Sampling of aerial populations at higher altitudes is not commonly undertaken, and we therefore consider that documentation of heteropteran flight records from such a sampling program carried out over eight seasons in southern England, when integrated with catch data from earlier aerial sampling over the UK, will advance our understanding of migration strategies in this abundant and ecologically-important group of insects.

In this paper we adopt an individual-based behavioural perspective on migration (Kennedy 1985; Dingle 1996; Dingle \& Drake, 2007; Chapman \& Drake, 2010). In the present context this assumes that insects caught high in the air, even relatively small ones like most Hemiptera, have usually ascended out of their "flight boundary layer" (Taylor, 1974) and entered the upper air as part of an adaptive migration syndrome [as revealed by, for example, J.S. Kennedy's classic experiments on Aphis fabae (Dingle, 2006)]: in general, they are not there "accidentally" or completely passively.

\section{METHODS}

Aerial sampling for high-flying migrant insects was carried out with a net suspended from a tethered helium-filled kytoon (blimp-shaped balloon) during the summers (various months between May and early September) of the years 1999, 2000, and 2002-2007. The sampling site was Cardington Airfield, Shortstown, Bedfordshire, UK $\left(52^{\circ} 06^{\prime} \mathrm{N}, 0^{\circ} 25^{\prime} \mathrm{W}\right)$, where the flying of tethered balloons above the normal Civil Aviation Authority limit of $60 \mathrm{~m}$ is permitted because of an official aircraft exclusion zone. The balloon-flying and aerial sampling procedures have been described in Chapman et al. (2004) but briefly, upper-air samples were taken at a height of $\sim 200 \mathrm{~m}$ semicontinuously with each $24-\mathrm{h}$ period generally divided up as follows: $1 \mathrm{~h}$ around dusk (ca. 21.00-22.00 h BST in July); night-time after the dusk period; "morning" (10.00-14:00 h); and afternoon (14:00-18:00). At the end of a sample period, a radio-controlled net closure device was used to close-off a detachable bag which formed the rear end of the net. The kytoon was then winched down to near ground level, and the bag containing the catch was removed and stored in a plastic killing bottle. A wind-run meter hung below the kytoon during each flight measured the wind run (approximating to the airflow through the net), from which the aerial density of insects in each sample could be estimated. The catch was later sorted and preserved, and the Heteroptera were identified to species by one of us (BSN), who retains voucher specimens.

The actual dates selected for sampling depended on logistical and financial considerations, but also on the weather - insect migration in Britain does not occur to any extent in cold or wet conditions. Besides this, kytoon flying was not undertaken at times of significant lightning risk or very strong winds. Occasionally, on fine days, winds at altitude were too weak (i.e. below $\sim 3 \mathrm{~m} / \mathrm{s}$ ) for efficient netting.

During fine weather, a surface temperature inversion is likely to form over land in the early evening, and the wind just below the top of the inversion often forms a low-level jet. Layers of migrant insects may form in the warm, fast-moving air at these altitudes ( 100-400 m) (Drake \& Farrow, 1988; Chapman et al., 2011) and it is therefore sensible to carry out night-time sampling within this altitude range, rather than say, sample in the colder stagnant air nearer the surface. The optimal height for daytime sampling is less clear-cut (because migrant insects will be circulated through various altitudes by convection currents), but the height of $\sim 200 \mathrm{~m}$ was convenient and was retained.

We compared our results with Heteroptera caught in highaltitude sampling programs carried out in England by Hardy \& Milne (1938), Freeman (1939, 1945), and Johnson \& Southwood (1949) who used kites, tall radio masts, and moored balloons, respectively, for net suspension. Results from samples taken in 1938 over the North Sea (with nets attached to ships' mast-heads) have also been included (Hardy \& Cheng, 1986). To engage in windborne (i.e. wind-assisted) migration an insect must actively penetrate above its "flight boundary layer" and maintain flight for a period of some minutes at the very least. Southwood (1962) considered that all heteropteran individuals caught at $50 \mathrm{ft}(15 \mathrm{~m})$ or more would be migrating and, consequently, we only included samples taken above this height in order to exclude short-duration "flits" (Southwood, 1960). Flitting is quite common in some heteropteran taxa (e.g. the Miridae) but these movements are "appetitive" (i.e. low-altitude local flights concerned with feeding and reproduction) rather than migratory in character. Accordingly, samples taken at $3 \mathrm{~m}$ in Freeman's study were omitted and only samples taken at his two upper heights $(54$ and $84 \mathrm{~m})$ were considered here. Southwood (1960, Table XI) presents some results from suction trapping at various heights (including 76 and $305 \mathrm{~m}$ in 1955) but species data are not given for specific heights above ground, so this information has been omitted from our tabulations (see below). We have, however, extracted from the collections of the Rothamsted Insect Survey heteropteran specimens caught at Cardington in August 1955 by means of 30-inch airscrew suction traps suspended from barrage balloons at $\sim 76 \mathrm{~m}(250 \mathrm{ft})$ and $\sim 305 \mathrm{~m}(1000 \mathrm{ft})$. These samples (identified by BSN) are referred to below as "Johnson \& Taylor, unpubl."; the trapping methodology is described in Johnson \& Taylor (1955).

\section{RESULTS}

Heteroptera caught at Cardington at ca. $200 \mathrm{~m}$ above ground during the present study are shown in Table 1, and Table 2 shows those caught at altitude at the same site in August 1955 (Johnson \& Taylor, unpubl. data). In 
TABLE 1. Heteroptera caught at $\sim 200 \mathrm{~m}$ above ground level at Cardington, Bedfordshire, 1999-2007.

\begin{tabular}{|c|c|c|c|c|c|c|c|c|c|c|c|c|}
\hline \multirow{2}{*}{ Family } & \multirow{2}{*}{ Species } & \multirow{2}{*}{ vii.99 } & \multirow{2}{*}{ vii.00 } & \multirow{2}{*}{ vii.02 } & \multirow{2}{*}{$\begin{array}{l}\text { viii.- } \\
\text { ix.03 }\end{array}$} & \multirow{2}{*}{ vii.04 } & \multirow{2}{*}{$\begin{array}{l}\text { vi.- } \\
\text { vii.05 }\end{array}$} & \multirow{2}{*}{$\begin{array}{l}\text { viii.- } \\
\text { ix.06 }\end{array}$} & \multirow{2}{*}{$\begin{array}{l}\text { vi.- } \\
\text { vii.07 }\end{array}$} & \multirow{2}{*}{ Sum } & \multicolumn{2}{|c|}{ Sex } \\
\hline & & & & & & & & & & & 우 & $\hat{0}$ \\
\hline \multirow{2}{*}{ Lygaeidae } & Kleidocerys resedae (Panzer) & & & & 7 & 1 & 5 & & 2 & 15 & 9 & 6 \\
\hline & Drymus sylvaticus (Fab.) & & & & & & 1 & 1 & & 2 & 2 & \\
\hline Tingidae & Acalypta parvula (Fallén) & & & & 1 & & & 1 & & 2 & 1 & 1 \\
\hline Reduviidae & Empicoris vagabundus (L.) & & & & & & & 1 & & 1 & & 1 \\
\hline Nabidae & Nabis flavomarginatus Scholtz & & & & & & 1 & & & 1 & 1 & \\
\hline \multirow{4}{*}{ Anthocoridae } & Anthocoris nemoralis (Fab.) & & 1 & & & & & & & 1 & 1 & \\
\hline & Anthocoris nemorum (L.) & & & & & 1 & & & & 1 & & 1 \\
\hline & Anthocoris simulans Reuter & & & & & & 1 & & & 1 & 1 & \\
\hline & Xylocoris galactinus (Fieber) & & 1 & & & & & & & 1 & 1 & \\
\hline \multirow{5}{*}{ Miridae } & Psallus varians (Herrich-Schaeffer) & & & & & & 1 & & & 1 & 1 & \\
\hline & Orthotylus tenellus (Fallén) & & & 1 & & & 1 & & & 2 & 2 & \\
\hline & Pinalitus cervinus (Herrich-Schaeffer) & 1 & 1 & & & & & 1 & & 3 & 2 & 1 \\
\hline & Capsus ater (L.) & & & & & & 1 & & & 1 & 1 & \\
\hline & Megaloceraea recticornis (Geoffroy) & & 1 & & & & & & & 1 & 1 & \\
\hline \multirow{2}{*}{ Corixidae } & Sigara distincta (Fieber) & & 1 & & & & & & & 1 & & 1 \\
\hline & Sigara lateralis (Leach) & & & & & & 1 & & & 1 & 1 & \\
\hline Total & & 1 & 5 & 1 & 8 & 2 & 12 & 4 & 2 & 35 & 24 & 11 \\
\hline
\end{tabular}

Table 3 these catches are compared with those from the sampling programs carried out in the 1930s and 40s. Johnson \& Southwood (1949) pointed out that Heteroptera generally comprise a very small proportion of insects caught at altitude, and this is substantiated by subsequent studies including the present one (Table 3). As can be seen, the proportions were generally $\sim 0.1-0.2 \%$ of the total catches, although Freeman obtained a slightly higher proportion $(0.6 \%)$. There is no doubt that the apertures of the tow-nets used in the sampling programs were undersized for optimal sampling of Heteroptera, but net size is strongly limited by practical considerations (such as the static and aerodynamic lift given by the moored kytoons in our case). Consequently, aerial samples in the UK are dominated by small or minute insects particularly aphids and certain families of small Diptera and parasitic Hymenoptera (Chapman et al., 2004); larger insects are infrequently caught. Nonetheless, the sky is immense and the recorded aerial catches of Heteroptera still represent large populations of migrants on the move (see below).

Considering all the tabulated studies, the most numerous heteropteran species captured were: Piesma maculatum (26 specimens), Lygus rugulipennis (22), Kleidocerys resedae (15), Drymus sylvaticus (11), Anthocoris nemorum (7), and A. confusus and Nabis ferus (4 each). Acompocoris pygmaeus, Xylocoris galactinus, Pinalitus cervinus and Orthops kalmii were each represented by three specimens, Taphropeltus contractus, Cymus claviculus, Acalypta parvula, Orius majusculus and Orthotylus tenellus by two, and the remaining species by singletons. We also note that $A$. nemorum (12 specimens), O. majusculus (12) and P. maculatum (11) were the commonest species caught in suction traps at various heights (between 3 and $305 \mathrm{~m}$ ) at Cardington in late August 1955 (Table XI in Southwood, 1960), and these records seem indicative of dispersive flight although, as

TABLE 2. Heteroptera caught at Cardington in August 1955. Samples taken by suction traps on barrage balloons at $76 \mathrm{~m}(250 \mathrm{ft})$, except* which were caught at $305 \mathrm{~m}(1000 \mathrm{ft})$.

\begin{tabular}{|c|c|c|c|c|}
\hline Family & Species & Sex & Date of capture & Time (BST) \\
\hline Lygaeidae & Nysius ericae & $\mathrm{f}$ & 23.viii.55 & $19.00-20.00$ \\
\hline \multirow{2}{*}{ Piesmatidae } & Piesma maculatum & $\mathrm{m}$ & 04.viii.55 & $13.00-14.00$ \\
\hline & P. maculatum* & $\mathrm{m}$ & 29.viii. 55 & $17.00-18.00$ \\
\hline Berytidae & Berytinus minor & $\mathrm{m}$ & 15.viii.55 & $12.00-13.00$ \\
\hline \multirow{10}{*}{ Anthocoridae } & Anthocoris nemorum & $\mathrm{f}$ & 20.viii.55 & $14.00-15.00$ \\
\hline & A. nemorum & $\mathrm{f}$ & 22.viii. 55 & $12.00-13.00$ \\
\hline & A. nemorum & $\mathrm{f}$ & 23.viii. 55 & $12.00-13.00$ \\
\hline & A. nemorum & $\mathrm{f}$ & 29.viii.55 & $13.00-14.00$ \\
\hline & Anthocoris confusus & $\mathrm{f}$ & 02.viii.55 & $10.00-11.00$ \\
\hline & A. confusus & $\mathrm{m}$ & 29.viii.55 & $16.00-17.00$ \\
\hline & A. confusus* & $\mathrm{f}$ & 29.viii.55 & $17.00-18.00$ \\
\hline & Anthocoris sp. & $\mathrm{f}$ & 30.viii.55 & $16.00-17.00$ \\
\hline & Acompocoris pygmaeus & $\mathrm{f}$ & 24.viii.55 & $12.00-13.00$ \\
\hline & A.pygmaeus & $\mathrm{f}$ & 25.viii.55 & $12.00-13.00$ \\
\hline Saldidae & Saldula saltatoria & $\mathrm{f}$ & 22.viii. 55 & $14.15-15.00$ \\
\hline
\end{tabular}


TABLE 3. Comparison of catches of Heteroptera obtained during aerial trapping studies over England and the North Sea.

\begin{tabular}{|c|c|c|c|c|c|c|c|c|c|c|c|c|c|}
\hline Study reference & \multicolumn{2}{|c|}{$\begin{array}{l}\text { Present } \\
\text { study }\end{array}$} & \multicolumn{2}{|c|}{$\begin{array}{l}\text { Freeman, } \\
1939,1945\end{array}$} & \multicolumn{2}{|c|}{$\begin{array}{l}\text { Hardy \& } \\
\text { Milne, } 1938\end{array}$} & \multicolumn{2}{|c|}{$\begin{array}{c}\text { Hardy \& } \\
\text { Cheng, } 1986\end{array}$} & \multicolumn{2}{|c|}{$\begin{array}{c}\text { Johnson \& } \\
\text { Southwood, } \\
1949\end{array}$} & \multicolumn{2}{|c|}{$\begin{array}{l}\text { Johnson \& } \\
\text { Taylor, } \\
\text { unpubl. }\end{array}$} & \multirow{7}{*}{ Total } \\
\hline Sampling location & \multicolumn{2}{|c|}{$\begin{array}{l}\text { Cardington, } \\
\text { Bedfordshire }\end{array}$} & \multicolumn{2}{|c|}{$\begin{array}{l}\text { Tetney, near } \\
\text { Grimsby }\end{array}$} & \multicolumn{2}{|c|}{$\begin{array}{l}\text { Hull, Suffolk } \\
\quad \& \text { Kent }\end{array}$} & \multicolumn{2}{|c|}{ North Sea } & \multicolumn{2}{|c|}{$\begin{array}{l}\text { Cardington, } \\
\text { Bedfordshire }\end{array}$} & \multicolumn{2}{|c|}{$\begin{array}{l}\text { Cardington, } \\
\text { Bedfordshire } \\
\end{array}$} & \\
\hline Year(s) & \multicolumn{2}{|c|}{$\begin{array}{l}1999,2000 \\
2002-2007\end{array}$} & \multicolumn{2}{|c|}{1934,1935} & \multicolumn{2}{|c|}{$1932-1935$} & \multicolumn{2}{|c|}{1938} & \multicolumn{2}{|c|}{1947,1948} & \multicolumn{2}{|c|}{1955} & \\
\hline Sampling Period & $\begin{array}{l}\text { May - } \\
\text { Septe }\end{array}$ & $\begin{array}{l}\text { early } \\
\text { mber }\end{array}$ & $\begin{array}{r}\text { Mar } \\
\text { Nove }\end{array}$ & $\begin{array}{l}\mathrm{ch}- \\
\text { mber }\end{array}$ & $\begin{array}{l}\text { Ap } \\
\text { Oct }\end{array}$ & $\begin{array}{l}\text { ril - } \\
\text { ober }\end{array}$ & $\begin{array}{r}\text { Jun } \\
\text { Octo }\end{array}$ & $\begin{array}{l}\text { e }- \\
\text { ber }\end{array}$ & $\begin{array}{r}\text { Ma } \\
\text { Nove }\end{array}$ & $\begin{array}{l}y- \\
\text { mber }\end{array}$ & $\mathrm{Au}$ & zust & \\
\hline Time of sampling & Day \& & night & Day & only & Day & only & Day \& & night & Day & only & Day 8 & night & \\
\hline Height of sampling & c. 20 & $0 \mathrm{~m}$ & $\begin{array}{r}54 \text { anc } \\
\text { on }\end{array}$ & $\begin{array}{l}84 \mathrm{~m} \\
\mathrm{y}^{\mathrm{a}}\end{array}$ & $546-$ & $610 \mathrm{~m}$ & $\begin{array}{r}\text { Fore } \\
\text { he }\end{array}$ & mast & $15-9$ & $14 \mathrm{~m}$ & 76 an & d 304 & \\
\hline Heteropteran family \& species & No. & $\%$ & No. & $\%$ & No. & $\%$ & No. & $\%$ & No. & $\%$ & No. & $\%$ & \\
\hline LYGAEIDAE & & & & & & & & & & & & & \\
\hline Kleidocerys resedae (Panzer) & 15 & 42.9 & & & & & & & & & & & 15 \\
\hline Nysius ericae (Schilling) & & & & & & & & & & & 1 & 6.7 & 1 \\
\hline Drymus sylvaticus (Fabricius) & 2 & 5.7 & 7 & 15.9 & & & & & 2 & 4.8 & & & 11 \\
\hline Taphropeltus contractus (Herrich-Schäffer) & & & 2 & 4.5 & & & & & & & & & 2 \\
\hline $\begin{array}{l}\text { Cymus claviculus (Fallén) } \\
\text { BerYTIDAE }\end{array}$ & & & 1 & 2.3 & 1 & 100.0 & & & & & & & 2 \\
\hline $\begin{array}{l}\text { Berytinus minor (Herrich-Schäffer) } \\
\text { PIESMATIDAE }\end{array}$ & & & & & & & & & & & 1 & 6.7 & 1 \\
\hline $\begin{array}{l}\text { Piesma maculatum (Laporte de Castelnau) } \\
\text { TINGIDAE }\end{array}$ & & & 22 & 50.0 & & & & & 2 & 4.8 & 2 & 13.3 & 26 \\
\hline $\begin{array}{l}\text { Acalypta parvula (Fallén) } \\
\text { REDUVIIDAE }\end{array}$ & 2 & 5.7 & & & & & & & & & & & 2 \\
\hline $\begin{array}{l}\text { Empicoris vagabundus (L.) } \\
\text { NABIDAE }\end{array}$ & 1 & 2.9 & & & & & & & & & & & 1 \\
\hline Nabis ferus (L.) & & & 2 & 4.5 & & & 1 & 50.0 & 1 & 2.4 & & & 4 \\
\hline $\begin{array}{l}\text { Nabis flavomarginatus Scholtz } \\
\text { ANTHOCORIDAE }\end{array}$ & 1 & 2.9 & & & & & & & & & & & 1 \\
\hline Anthocoris nemoralis (Fabricius) & 1 & 2.9 & & & & & & & & & & & 1 \\
\hline Anthocoris nemorum (L.) & 1 & 2.9 & & & & & & & 2 & 4.8 & 4 & 26.7 & 7 \\
\hline Anthocoris confusus Reuter & & & 1 & 2.3 & & & & & & & 3 & 20.0 & 4 \\
\hline $\begin{array}{l}\text { Anthocoris simulans Reuter } \\
\text { (formerly } A \text {. minki) }\end{array}$ & 1 & 2.9 & & & & & & & & & & & 1 \\
\hline Anthocoris spp. & & & & & & & & & 2 & 4.8 & 1 & 6.7 & 3 \\
\hline Acompocoris pygmaeus (Fallén) & & & & & & & & & 1 & 2.4 & 2 & 13.3 & 3 \\
\hline Orius majusculus (Reuter) & & & & & & & & & 2 & 4.8 & & & 2 \\
\hline Xylocoris galactinus (Fieber) & 1 & 2.9 & & & & & & & 2 & 4.8 & & & 3 \\
\hline $\begin{array}{l}\text { Unidentified Anthocoridae } \\
\text { MIRIDAE }\end{array}$ & & & 1 & 2.3 & & & & & 1 & 2.4 & & & 2 \\
\hline Monalocoris filicis (L.) & & & 1 & 2.3 & & & & & & & & & 1 \\
\hline Psallus varians (Herrich-Schaeffer) & 1 & 2.9 & & & & & & & & & & & 1 \\
\hline Orthotylus tenellus (Fallén) & 2 & 5.7 & & & & & & & & & & & 2 \\
\hline Mecomma dispar (Boheman) & & & 1 & 2.3 & & & & & & & & & 1 \\
\hline Lygus rugulipennis Poppius * & & & & & & & & & 22 & 52.4 & & & 22 \\
\hline Liocoris tripustulatus (Fabricius) & & & & & & & & & 1 & 2.4 & & & 1 \\
\hline Pinalitus cervinus (Herrich-Schaeffer) & 3 & 8.6 & & & & & & & & & & & 3 \\
\hline Orthops kalmii (L.) & & & & & & & & & 3 & 7.1 & & & 3 \\
\hline Capsus ater (L.) & 1 & 2.9 & & & & & & & & & & & 1 \\
\hline Stenodema calcarata (Fallén) & & & & & & & 1 & 50.0 & & & & & 1 \\
\hline Megaloceraea recticornis (Geoffroy) & 1 & 2.9 & & & & & & & & & & & 1 \\
\hline Leptopterna ferrugata (Fallén) & & & 1 & 2.3 & & & & & & & & & 1 \\
\hline $\begin{array}{l}\text { Unidentified Miridae } \\
\text { SALDIDAE }\end{array}$ & & & 2 & 4.5 & & & & & 1 & 2.4 & & & 3 \\
\hline $\begin{array}{l}\text { Saldula saltataria }(\mathrm{L} .) \\
\text { CORIXIDAE }\end{array}$ & & & & & & & & & & & 1 & 6.7 & 1 \\
\hline Sigara lateralis (Leach) & 1 & 2.9 & & & & & & & & & & & 1 \\
\hline Sigara distincta (Fieber) & 1 & 2.9 & & & & & & & & & & & 1 \\
\hline Undetermined & & & 3 & 6.8 & & & & & & & & & 3 \\
\hline Total Heteroptera & 35 & 100 & 44 & 100 & 1 & 100 & 2 & 100 & 42 & 100 & 15 & 100 & 139 \\
\hline Total insects and \% Heteroptera & 17752 & 0.20 & 7748 & 0.57 & 839 & 0.12 & $1946^{\mathrm{b}}$ & 0.10 & 35447 & $0.12^{\mathrm{s}}$ & - & - & \\
\hline
\end{tabular}


TABLE 4. Seasonal distribution of aerial catches of Heteroptera, with information on overwintering stage and number of generations.

\begin{tabular}{|c|c|c|c|}
\hline $\begin{array}{l}\text { Heteropteran family } \\
\& \text { species }\end{array}$ & $\begin{array}{l}\text { Month (date) of high-altitude } \\
\text { capture* }\end{array}$ & $\begin{array}{l}\text { Overwintering stage } \\
\mathrm{A} \text { - adult, } \mathrm{E} \text { - egg }\end{array}$ & $\begin{array}{l}\text { Number of generations } \\
\text { in England }{ }^{\#}\end{array}$ \\
\hline LYGAEIDAE & & & \\
\hline Kleidocerys resedae & Late May (20th) to early September (8th) & A & 2 (at least in S England) \\
\hline Nysius ericae & August (23rd) & $\mathrm{E}$ & 2 \\
\hline Drymus sylvaticus & June. Late August - September & A & 2 (2nd may be partial) \\
\hline Taphropeltus contractus & August-September & A & $1 ?$ \\
\hline $\begin{array}{l}\text { Cymus claviculus } \\
\text { BERYTIDAE }\end{array}$ & June. August-September ${ }^{s}$ & A & 1 \\
\hline $\begin{array}{l}\text { Berytinus minor } \\
\text { PIESMATIDAE }\end{array}$ & August (15th) & A & 1 (possibly 2 ) \\
\hline $\begin{array}{l}\text { Piesma maculatum } \\
\text { TINGIDAE }\end{array}$ & June. August-September & A & 2 \\
\hline $\begin{array}{l}\text { Acalypta parvula } \\
\text { REDUVIIDAE }\end{array}$ & August & A & 1 \\
\hline $\begin{array}{l}\text { Empicoris vagabundus } \\
\quad \text { NABIDAE }\end{array}$ & August (5th) & A & 1 \\
\hline Nabis ferus & June. August-September & A & 1 \\
\hline $\begin{array}{l}\text { Nabis flavomarginatus } \\
\text { ANTHOCORIDAE }\end{array}$ & July (10th) & $\mathrm{E}$ & 1 \\
\hline Anthocoris nemoralis & July (18th) & A & 2 \\
\hline Anthocoris nemorum & July-August & $\mathrm{A}$ & 2 or even 3 \\
\hline Anthocoris confusus & August-September & A & 2 \\
\hline Anthocoris simulans & June (19th) & presumably A & $?$ \\
\hline Anthocoris spp. & August & & - \\
\hline Acompocoris pygmaeus & Late August & probably A & 2 \\
\hline Orius majusculus & August-September & A (mostly female) & at least 2 \\
\hline $\begin{array}{l}\text { Xylocoris galactinus } \\
\text { MIRIDAE }\end{array}$ & July-August & Semi-continuous development & Multivoltine \\
\hline Monalocoris filicis & September & A & 1 \\
\hline Psallus varians & June (17th) & $\mathrm{E}$ & 1 \\
\hline Orthotylus tenellus & June-July & $\mathrm{E}$ & 1 \\
\hline Mecomma dispar & July & $\mathrm{E}$ & 1 \\
\hline Lygus rugulipennis & $\begin{array}{l}\text { Late August (22nd) to October (20th) } \\
\text { (many in early October) }\end{array}$ & A & 2 \\
\hline Liocoris tripustulatus & August (22nd) & A & 1 \\
\hline Pinalitus cervinus & July-August & A (in UK) & 2 \\
\hline Orthops kalmii & August & $\mathrm{A}$ & 1 \\
\hline Capsus ater & June (17th) & $\mathrm{E}$ & 1 \\
\hline Stenodema calcarata & (between June \& October) & $\mathrm{A}$ & 1 \\
\hline Megaloceraea recticornis & July $(21 \mathrm{st})$ & $\mathrm{E}$ & 1 \\
\hline $\begin{array}{l}\text { Leptopterna ferrugata } \\
\text { SALDIDAE }\end{array}$ & June-July $\$$ & $\mathrm{E}$ & 1 \\
\hline $\begin{array}{l}\text { Saldula saltatoria } \\
\text { CORIXIDAE }\end{array}$ & August (22nd) & A & $1 ?$ \\
\hline Sigara lateralis & July (10th) & A & 2 or possibly 3 \\
\hline Sigara distincta & July (17th) & $\mathrm{A}$ & 2 (2nd may be partial) \\
\hline
\end{tabular}

* For single specimens the exact date of capture is given, if available. * May be fewer in Scotland. ${ }^{\$}$ For some of Freeman's (1945) specimens it is not possible to distinguish the month of high-altitude captures (as dates may include low-altitude catches).

previously mentioned, the exact heights of capture of each specimen were not presented.

It will be seen (Table 3) that the predominant species in the early studies, i.e. P. maculatum and L. rugulipennis were not caught at all during our sampling program, and the converse was true for $K$. resedae. The relative decline in populations of L. rugulipennis may be due to a reduction in the main host plants, arable weeds, since modern herbicides came into use. In the case of $P$. maculatum, this species is now sparsely scattered in Bedfordshire (i.e. in the locality of the aerial sampling) and is found mainly on Chenopodiaceae on manure heaps (B.S. Nau, pers. observ.); the decline of livestock farming in the county over the last half-century will have reduced the availability of this habitat. Conceivably, the greater abundance in recent times of the arboreal $K$. resedae may be associated with the expansion of its host range, e.g. onto Buddleia and maybe other hosts (Southwood, 2005). Drymus 
sylvaticus, A. nemorum and X. galactinus were taken in both the early and the present studies.

The small numbers of specimens captured generally preclude detailed analysis of diel flight periodicity, but the numbers of $K$. resedae were perhaps large enough to extract some information on this topic. Nine individuals of $K$. resedae were caught in our daytime samples, producing an average aerial density of 2.8 per $10^{5} \mathrm{cu} . \mathrm{m}$ ( \pm 2.7 s.d.). However, the five specimens taken at dusk produced a higher average density $\left[6.2\right.$ per $10^{5} \mathrm{cu} . \mathrm{m}$ $( \pm 1.3)]$, and one specimen was taken later in the night (after $22.00 \mathrm{~h}$ ). It would appear, therefore, that some $K$. resedae individuals that have ascended during the day may maintain flight at nightfall, perhaps with some concentration at the top of the nocturnal temperature inversion (as occurs in aphid populations under some circumstances: Riley et al., 1995; Reynolds et al., 1999). Alternatively, other individuals may exhibit crepuscular emigration. It should be noted that flight after dark would not be assisted by fair-weather convective updraughts, and that migrants would have to maintain altitude by their own efforts. Migrants flying at about $200 \mathrm{~m}$ above ground at this time would be able to utilise the local wind maximum which typically develops at the top of the surface inversion, and movement over at least tens of kilometres could readily occur. All in all, the pattern of captures is indicative of a high migratory propensity in $K$. resedae.

Apart from the $K$. resedae specimen mentioned above, the only night-time (i.e. after $22.00 \mathrm{~h}$ ) captures by us were a specimen of the reduviid Empicoris vagabundus and one of the mirid Orthotylus tenellus - in the latter case this agrees with the statement of Southwood (1960) that the species is a crepuscular or nocturnal flyer.

It should be noted that densities such as those recorded for $K$. resedae are indicative of large aerial population fluxes. Considering periods when this species was caught, our aerial samples indicted that on average 1.95 individuals passed through a $1-\mathrm{m}^{2}$ aperture at the sampling altitude. If we assume that the density applies to, say, a 100-m high "window" positioned around the altitude of the net, then this would be equivalent to $\sim 2$ million of the bugs, on average, crossing a $10-\mathrm{km}$ line oriented at rightangles to their direction of movement.

The month (or date) of the aerial captures is shown in Table 4. We discuss below how this information may be tentatively related to life-cycles of populations in the UK, and to seasonal emigrations from hibernation or breeding sites.

\section{DISCUSSION}

Unlike the earlier aerial sampling programs, we sampled at dusk and night-time as well as during the day. However, most of the Heteroptera caught by us were, in fact, taken during the day (between ca. 10.00 and 18.00 h), so migrants seemingly benefit from convective updraughts to assist ascent. Heteroptera as a group show more flight activity during the day, particularly in temperate regions (Southwood, 1960), and we note that
Glick's (1939) aeroplane trapping program, mainly in Louisiana, caught more terrestrial Heteroptera during the day than the night.

The time migrants spent aloft is, of course, not known exactly. However, it is probably at least $\sim 10-15 \mathrm{~min}$, because it would take this time to reach an altitude of 200 $\mathrm{m}$ assuming a self-propelled ascent rate of $\sim 0.25 \mathrm{~m} / \mathrm{s}$ (the crespucular fliers, at least, would be unassisted by updrafts). A 15-min flight at the average wind speed of $5.5 \mathrm{~m} / \mathrm{s}$ (recorded by us at $200 \mathrm{~m}$ during periods when bugs were actually caught) would produce a migration distance of $\sim 5 \mathrm{~km}$. Southwood's (1960) laboratory measurements of flight duration in $P$. maculatum recorded a minimum of $15 \mathrm{~min}$; the longest continuous flight was 75 min which would result in a migration distance of $\sim 25 \mathrm{~km}$ in a $5.5 \mathrm{~m} / \mathrm{s}$ wind. Another species trapped at altitude, Berytinus minor, flew for $42 \mathrm{~min}$ in the laboratory (Southwood, 1960). We also note that Leptoglossus occidentalis flights mentioned in the Introduction would have required a flight time sufficient to travel across the English Channel. It is clear that even under our rather conservative assumptions the windborne flights produce significant migration ambits.

\section{Migration and habitat stability}

As mentioned above, the hypothesis that degree of migratoriness found in a taxon is associated with the impermanence of its habitat owes much to the early trapping studies of Heteroptera by Southwood and others (e.g. Johnson \& Southwood, 1949; Brown, 1951; Southwood, 1960, 1962, and 2004 pers. com.). Migrating when new habitats are being formed enables animals to colonise these habitat patches, and exploit newly-available resources. Therefore, denizens of unstable or temporary habitats - e.g. host plants that are short-lived (annuals, particularly arable weeds, or members of successional stages e.g. on wastelands), flowers, manure and plantdebris heaps - are more likely to be migrants than those of more "permanent" habitats such as woodland trees (Southwood, 1962). The precise nature of the resources required may not be easy to determine; for example, the grass bug Megaloceraea recticornis, unlike some other Stenodemini (and contrary to earlier reports), requires grass flowers for development and cannot survive on leaves alone (Wetton \& Gibson, 1987). Migration is also to be expected in species whose hosts, although perennial, are distributed in small patches within an extensive inhospitable "matrix" (Solbreck, 1985). The presence of heteropterans high in the air is a much clearer indicator that individuals are highly migratory than catches in traps near the ground, and so one would expect the species recorded at altitude (see Table 3 ) to be characteristic of relatively ephemeral habitats. Considering the habitats and feeding strategies (information obtained from Southwood \& Leston (1959), Southwood (1960) and B.S. Nau, pers. observ.) this contention seems, in general, to be borne out. For example, P. maculatum, L. rugulipennis, and Orthops kalmii are found on weeds, and Nabis ferus, $N$. flavomarginatus and Stenodema calcarata characteristically occur on grass species. 
Amongst inhabitants of low-growing vegetation, migratory species are more likely to be found in the drier biotopes which commonly have rather transient plant communities (Southwood, 1960), and our results support this. Considering the Lygaeidae caught, Drymus sylvaticus is found "amongst moss, grass and leaf-litter on almost all dryish soils", Taphropeltus contractus occurs "on dry sandy, cindery or chalk wastelands" and Cymus claviculus in "somewhat dry meadows" (Southwood \& Leston, 1959). In the UK, Nysius ericae is common in dry, sparsely vegetated habitats with a large component of bare ground [and we note, incidentally, that individuals attributed to this species were common heteropterans in airplane catches up to $900 \mathrm{~m}$ over Louisiana and Mexico (Glick, 1939)]. The tingid Acalytpa parvula is associated with short moss particularly on dry soils (Southwood \& Leston, 1959), while among the Miridae, Stenodema calcarata, which feeds on grains of a number of grasses, is often commoner in drier habitats than other members of the Stenodemini (Southwood, 1960), and Leptopterna ferrugata occurs in drier, more exposed grassland than its congener L. dolabrata (Southwood \& Leston, 1959).

Even in predominantly predatory heteropterans, there is often a preference for particular types of vegetation (Wheeler, 2001). Among the Anthocorid predators, for example, species captured at altitude are usually associated with relatively exposed habitats: Orius majusculus is associated with flowers, and Anthocoris nemorum prefers lower herbage to trees. Xylocoris galactinus (the hot-bed bug) specializes in living in hot, moist habitats such as manure heaps, hot-beds, vegetable refuse, grain stores, etc. (Adult $X$. galactinus are used by phoretic deutonymphs (hypopi) of tyroglyphid mites (Southwood \& Leston, 1959), and this phoresy is, itself, evidence of the impermanence of the habitat). Other species of Anthocoris (nemoralis, confusus) although more characteristically found on trees than is A. nemorum, are nonetheless free-living generalist predators that track temporary resources, namely their arthropod prey [as is shown by studies directed at using these bugs for biological control in orchards (e.g. Shaltiel \& Coll, 2004)].

The high mobility of some other arboreal species may be associated with a degree of carnivory - as well as feeding on their host plant, their diet may include small arthropod prey, for example, in the mirids Orthotylus tenellus or Psallus varians. Dependence or partial dependence on prey such as aphids, psyllids or spider mites means that the heteropterans may have to migrate between host plants in order to "track" prey infestations movements of this sort are well-documented in some Anthocoris spp. (see below).

Some phytophagous bugs, although living on trees and shrubs, are not exceptions to the habitat impermanence hypothesis because they are not general feeders but dependent on flowers or ripening seeds which are, of course, a temporary commodity [see Southwood's (1962) comments on Dysdercus]. Kleidocerys resedae which is usually found on trees is the obvious example here, as it exploits birch and alder catkins and Buddleia seeds.
Freeman (1945) commented on a very rare macropterous female of Mecomma dispar taken in his highest trap, and we found an unusual macropterous female of Nabis flavomarginatus. These cases indicate that the species concerned have not entirely evolved towards a sedentary life-history. Zera \& Denno (1997) cite evidence that dispersal capability of the macropter is reduced for species in which the proportion of macropters is low. Nonetheless, windborne movements were evidently taking place in the two species with rare macropters mentioned above (c.f. the apparent genetic homogeneity in populations of a delphacid planthopper with $>99 \%$ flightless adults (Peterson et al., 2001), one explanation of which was that the rare macropters could still be important ecologically if they moved long distances). It should be noted that the mere retention of flight ability in wing-dimorphic Heteroptera is not necessarily indicative of a migratory propensity - many arboreal phytophagous species retain flight capabilities even though they live on persistent hosts, presumably due to the architectural complexity of their habitat (Waloff, 1983; Denno et al., 2001); flightcapable males, for instance, will find it easier to locate females in sparse and discontinuous vegetation.

Of the corixids caught at altitude, Sigara lateralis are frequent migrants (Southwood \& Leston, 1959; Popham, 1964) which is not surprising as typical habitats consist of smallish water bodies (ponds, ditches, cattle troughs, sewage tanks). It sometimes flies en masse, and Boda \& Csabai (2009) captured quite large numbers using polarotactic attraction to black plastic sheets. Sigara distincta is found in a variety of lakes and meres, but usually near emergent vegetation (Southwood \& Leston, 1959) and it is associated with moderate concentrations of organic matter rather than highly oligotrophic lakes (e.g. Savage, 1990).

\section{Migration, phenology and voltinism}

Table 4 shows that high-altitude sampling effort in the UK has been mainly concentrated in the mid-summer to autumn period, but Freeman $(1939,1945)$ sampled from March, and Johnson \& Southwood (1949) and ourselves took some samples in May. The earliest named specimen caught appears to have been a $K$. resedae individual taken in the present study on 20 May, and a further three $K$. resedae and a $D$. sylvaticus were caught by us in early June $\left(9^{\text {th }}\right)$. Freeman (1939) caught most of his P. maculatum specimens in June.

In the British Isles, many heteropteran species overwinter as adults, and the majority of the species caught at altitude are known to overwinter in this stage (see Table 4). In some genera, both sexes overwinter in some form of reproductive diapause, but in others (e.g. Anthocoris and Orius spp.) it is mainly the fertilised females which survive until spring. Be that as it may, it seems clear that captures in spring and early summer represent posthibernation flights when adults become active again and attempt to regain hosts suitable for feeding, oviposition, etc. (Southwood \& Leston, 1959; Southwood, 1960; Collyer, 1967; Stewart, 1968, and references therein). It seems likely that this migration has only been partially 
documented by the aerial sampling because emergence from overwintering sites can start as early as March or April in some species (e.g. Anthocoris spp., $P$. maculatum, L. rugulipennis, N. ferus, Sigara spp.) in some years (Southwood, 1960; Anderson, 1962; Popham, 1964; Collyer, 1967; Stewart, 1968, Saulich \& Musolin, 2009). Detection of post-hibernation flights may also be hampered by low numbers, as winter mortality can be very high (e.g. $67-95 \%$ in the Nabis spp. studied by Roth \& Reinhardt, 2009). Nonetheless, considerable daytime flight activity after hibernation is sometimes mentioned in the literature, e.g. for $P$. maculatum and A. parvula (Southwood, 1960), perhaps due to flight being synchronised by fine weather in spring/early summer (Southwood \& Johnson, 1957).

In the case of L. rugulipennis, where no early-season flight was recorded in the aerial samples, we note that Ashmole et al. (1983) collected seven individuals of this species in June and July1979 from snowfields near the summits of the Cairngorm Mountains, Scotland. This fall-out was evidently a manifestation of long-distance migration, perhaps attributable to a late post-hibernation flight by populations which are univoltine under Scottish conditions.

Southwood (1960) suggested that many lygaeids (Drymus, Taphropeltus) and Piesma have long duration posthibernation flights, while "flitting" may be more common in species that overwinter in the egg stage as is often the case in the Miridae [although adult overwintering occurs in some mirid species, especially those whose hosts are early-successional plants (Wheeler, 2001)]. Presumably finding suitably sheltered sites for adult hibernation is more likely to require a change of location, than is the placement of overwintering eggs. And in any case, the oviposition of diapausing eggs must be on a favourable host for the first instar nymphs emerging the following spring, while overwintered adults can disperse again in the spring and search for suitable hosts.

Aerial captures late in the year (August, September and October) by us and earlier authors very probably represent a dispersive flight before adults enter hibernacula (or in the case of aquatic bugs, water bodies suitable for overwintering). Where populations have been able to build-up through the summer, there may be considerable "pre-hibernation flight" activity in autumn, e.g. in $L$. rugulipennis (Johnson \& Southwood, 1949; Southwood \& Leston, 1959). Stewart (1968) provides information on flights to hibernacula in L. rugulipennis, based on earlier papers and on his own work, and these observations may well have application to other species migrating at this stage in their life-cycle. The pre-hibernation flights of $L$. rugulipennis were clearly distinguishable from "flits" from plant to plant within the habitat, and they often covered considerable distances, e.g. adults might fly to a distant wood rather than just to a hedgerow round a field. Sometimes in September and October, individuals were seen to fly strongly upwards at a steep angle until they were out of sight (Stewart, 1968); clearly this could take them to heights where, assisted by up-currents, they can engage in high-altitude windborne migration (Johnson \& Southwood, 1949).

Finally, we note that bivoltine and multivoltine species (such as P. maculatum, Anthocoris spp., O. majusculus, Sigara spp. - see Table 4) may also undertake some intergenerational redistribution between habitat patches or host-plant types during the summer. For example, overwintered adults of $A$. nemorum are first found abundantly on flowering trees (particularly willows) where they feed on aphid and psyllid colonies, but later these adults and/or later generations occurred mostly on herbaceous vegetation (Collyer, 1967; Saulich \& Musolin, 2009). The highaltitude trapping catches of A. nemorum in July-August probably represent the first summer generation, but catches in late August could include some early fliers of the second summer generation (in August the generations overlap; Anderson, 1962); the same applies to Southwood's (1960) A. nemorum records in elevated suction traps in late August. Other Anthocoris spp. e.g. A. nemoralis also make quite structured movements between host plant types in order to take advantage of the seasonal availability of favoured prey (Anderson, 1962; Saulich \& Musolin, 2009). In D. sylvaticus, the combined catches of Johnson and Southwood, Freeman, and ourselves indicate that the species occurs at altitude most frequently in late August-September, but as there may be a (sometimes partial) second generation before the end of the year, these flights may be intergenerational rather than prehibernation. In some of these bivoltine/trivoltine species, numbers are able to build-up considerably during the summer, and the migratory flight of the second (or the last) generation of the season is likely to be more apparent than the earlier flights, as noted above. Interestingly, Collyer (1967) found that the A. nemorum second generation was often larger in habitats subject to cultivation or insecticide spraying than in less disturbed habitats; the species was often the first to re-establish itself in orchards after it was eliminated by insecticide spraying which in itself indicates a high degree of mobility.

In conclusion, despite the preliminary nature of the results presented, we can say that at certain seasons and in suitable weather the airborne migrant heteropteran population over Britain, and by extension over Northwest Europe, will be huge. It is also apparent that some common species tend to occur frequently in the aerial samples while others, many mirids for example, were not caught at altitude. (Clearly no significance can be attributed to any absences of the less common or rare species.) This species composition is largely consistent with current notions of migratoriness as an adaptation for dealing with environmental stochasticity, and the timing of flights fits in well with what is known of the species' seasonal phenologies.

ACKNOWLEDGEMENTS. We thank the Director of the Meteorological Research Unit (UK Meteorological Office) for permission to operate the balloon within the official aircraft exclusion zone at Cardington, and thank D. Bamber and other Met Office staff for their advice on various practical and administrative aspects of the flying operations. We are especially 
indebted to A. Smith (Rothamsted) for help in organising the aerial sampling programs; S. Dunn, R. Selby, D. Sivell, E. Smith and C. Wood assisted with the balloon handling and sorting of the aerial catches during particular field trips. Rothamsted Research is a national institute of bioscience strategically funded by the UK Biotechnology and Biological Sciences Research Council (BBSRC).

\section{REFERENCES}

Anderson N.H. 1962: Bionomics of six species of Anthocoris (Heteroptera: Anthocoridae) in England. - Trans. R. Entomol. Soc. Lond. 114: 67-95.

ANDERSEN N.M. 2000: The evolution of dispersal dimorphism and other life history traits in water striders (Hemiptera: Gerridae). - Entomol. Sci. 3: 187-199.

Ashmole N.P., Nelson J.M., Shaw M.R. \& Garside A. 1983: Insects and spiders on snowfields in the Cairngorms, Scotland. - J. Nat. Hist. 17: 599-613.

Boda P. \& Csabai Z. 2009: Seasonal and diel dispersal activity characteristics of Sigara lateralis (Leach, 1817) (Heteroptera: Corixidae) with special emphasis on possible environmental factors and breeding state. - Aquat. Insects 31: 301-314.

BRown E.S. 1951: The relation between migration-rate and type of habitat in aquatic insects, with special reference to certain species of Corixidae. - Proc. Zool. Soc. Lond. 121: 539-545.

Brown E.S. 1965: Notes on the migration and direction of flight of Eurygaster and Aelia species (Hemiptera, Pentatomoidea) and their possible bearing on invasions of cereal crops. $-J$. Anim. Ecol. 34: 93-107.

Chapman J.W. \& Drake V.A. 2010: Insect migration. In Breed M.D. \& Moore J. (eds): Encyclopedia of Animal Behavior. Vol. 2. Academic Press, Oxford, pp. 161-166.

Chapman J.W., Reynolds D.R., Smith A.D., Smith E.T. \& WorwoD I.P. 2004: An aerial netting study of insects migrating at high-altitude over England. - Bull. Entomol. Res. 94: 123-136.

Chapman J.W., Drake V.A. \& Reynolds D.R. 2011: Recent insights from radar studies of insect flight. - Annu. Rev. Entomol. 56: 337-356.

COLLYer E. 1967: On the ecology of Anthocoris nemorum (L.) (Hemiptera - Heteroptera). — Proc. R. Entomol. Soc. Lond. (A) 42: 107-118.

Denno R.F., Gratton C. \& Langellotto G.A. 2001: Significance of habitat persistence and dimensionality in the evolution of insect dispersal strategies. In Woiwood I.P., Reynolds D.R. \& Thomas C.D. (eds): Insect Movement: Mechanisms and Consequences. $\mathrm{CAB}$ International, Wallingford, $\mathrm{pp}$. 235-259.

Dingle H. 1974: Diapause in a migrant insect, the milkweed bug Oncopeltus fasciatus (Dallas) (Hemiptera: Lygaeidae). Oecologia 17: 1-10.

Dingle H. 1982: Function of migration in the seasonal synchronization of insects. - Entomol. Exp. Appl. 31: 36-48.

DingLE H. 1991: Factors influencing spatial and temporal variation in abundance of the large milkweed bug (Hemiptera: Lygaeidae). - Ann. Entomol. Soc. Am. 84: 47-51.

Dingle H. 1996: Migration: the Biology of Life on the Move. Oxford University Press, Oxford, 474 pp.

Dingle H. 2001: The evolution of migratory syndromes in insects. In Woiwood I.P., Reynolds D.R. \& Thomas C.D. (eds): Insect Movement: Mechanisms and Consequences. CAB International, Wallingford, pp. 159-181.

DiNGLE H. 2006: Animal migration: Is there a common migratory syndrome? - J. Ornith. 147: 212-220.
Dingle H. \& Drake V.A. 2007: What is migration? - BioScience 57: 113-121.

DRAKE V.A. \& FARROW R.A. 1988: The influence of atmospheric structure and motions on insect migration. - Annu. Rev. Entomol. 33: 183-210.

Duviard D. 1977: Migration of Dysdercus spp. (Hemiptera: Pyrrhocoridae) related to movements of the inter-tropical convergence zone in West Africa. — Bull. Entomol. Res. 67: $185-204$.

Freeman J.A. 1939: Studies in the Distribution of Insects by Aerial Currents. A Contribution to the Study of Windborne Insects with Special Reference to Vertical Distribution and Dispersal. PhD Thesis, University College, Hull, UK.

FREEMAN J.A. 1945: Studies in the distribution of insects by aerial currents. The insect population of the air from ground level to 300 feet. - J. Anim. Ecol. 14: 128-154.

GLICK P.A. 1939: The distribution of insects, spiders and mites in the air. Technical Bulletin No. 673, United States Department of Agriculture, Washington, D.C., $151 \mathrm{pp}$.

GLICK P.A. 1957: Collecting insects by airplane in southern Texas. Technical Bulletin No. 1158, United States Department of Agriculture, Washington, D.C., 28 pp.

Gressitt J.L., SedlaceK J., Wise K.A.J. \& Yoshimoto C.M. 1961: A high speed airplane trap for airborne organisms. Pacif. Insects 3: 549-555.

HaRdy A.C. \& Cheng L. 1986: Studies in the distribution of insects by aerial currents. III. Insect drift over the sea. Ecol. Entomol. 11: 283-290.

Hardy A.C. \& Milne P.S. 1938: Studies in the distribution of insects by aerial currents. Experiments in aerial tow-netting from kites. - J. Anim. Ecol. 7: 199-229.

JoHnson C.G. 1969: Migration and Dispersal of Insects by Flight. Methuen, London, xxii +763 pp.

Johnson C.G. \& Southwood T.R.E. 1949: Seasonal records in 1947 and 1948 of flying Hemiptera - Heteroptera, particularly Lygus pratensis L., caught in nets $50 \mathrm{ft}$. to $3,000 \mathrm{ft}$. above the ground. - Proc. R. Entomol. Soc. Lond. (A) 24: $128-130$.

JoHNSON C.G. \& TAYLOR L.R. 1955: The development of large suction traps for airborne insects. - Ann. Appl. Biol. 43: $51-62$.

KenNEDy J.S. 1985: Migration, behavioural and ecological. In Rankin M.A. (ed.): Migration: Mechanisms and Adaptive Significance. - Contr. Marine Sci. 27 (Suppl.): 5-26.

KERZHNER I.M. 1983: Airborne Nabis capsiformis (Heteroptera: Nabidae) from the Atlantic, Indian, and Pacific Oceans. Int. J. Entomol. 25: 273-275.

Malumphy C., Botting J., Bantock T. \& Reid S. 2008: Influx of Leptoglossus occidentalis Heidemann (Coreidae) in England. - Het. News 12: 7-9.

McDonald G. \& Farrow R.A. 1988: Migration and dispersal of the Rutherglen bug, Nysius vinitor Bergroth (Hemiptera: Lygaeidae), in eastern Australia. - Bull. Entomol. Res. 78: 493-509.

Peterson M.A., Denno R.F. \& Robinson L. 2001: Apparent widespread gene flow in the predominantly flightless planthopper Tumidagena minuta. - Ecol. Entomol. 26: 629-637.

PopHAM E.J. 1964: The migration of aquatic bugs with special reference to the Corixidae (Hemiptera, Heteroptera). - Arch. Hydrobiol. 60: 450-496.

Reynolds D.R., Mukhopadhyay S., Riley J.R., Das B.K., Nath P.S. \& MANDAL S.K. 1999: Seasonal variation in the windborne movement of insect pests over northeast India. - Int. J. Pest Manag. 45: 195-205.

Riley J.R., Reynolds D.R. \& FARRow R.A. 1987: The migration of Nilaparvata lugens (Stål) (Delphacidae) and other Hemi- 
ptera associated with rice, during the dry season in the Philippines: a study using radar, visual observations, aerial netting and ground trapping. — Bull. Entomol. Res. 77: 145-169.

Riley J.R., Reynolds D.R., Mukhopadhyay S., Ghosh M.R. \& SARKAR T.K. 1995: Long-distance migration of aphids and other small insects in northeast India. — Eur. J. Entomol. 92 : 639-653.

Roth S. \& Reinhardt K. 2009: Sexual dimorphism in winter survival rate differs little between damselbug species (Heteroptera: Nabidae). — Eur. J. Entomol. 106: 37-41.

Saulich A.KH. \& Musolin D.L. 2009: Seasonal development and ecology of anthocorids (Heteroptera, Anthocoridae). Entomol. Rev. 89: 501-528.

SAvage A.A. 1990: The distribution of Corixidae in lakes and the ecological status of the north-west Midlands meres. Field Studies 7: 516-530.

Shaltiel L. \& Coll M. 2004: Reduction of pear psylla damage by the predatory bug Anthocoris nemoralis (Heteroptera: Anthocoridae): the importance of orchard colonization time and neighboring vegetation. - Biocontr. Sci. Technol. 14 811-821.

Socha R. \& Šula J. 2006: Flight muscles polymorphism in a flightless bug, Pyrrhocoris apterus (L.): developmental pattern, biochemical profile and endocrine control. - J. Insect Physiol. 52: 231-239.

Socha R., Kodrík D. \& Šula J. 2005: Wing morph-specific differences in the metabolism and endocrine control of reserve mobilization in adult males of a flightless bug, Pyrrhocoris apterus (L.) (Heteroptera). — J. Comp. Physiol. (B) 175: 557-565.

SolBreck C. 1985: Insect migration strategies and population dynamics. In Rankin M.A. (ed.): Migration: Mechanisms and Adaptive Significance. Contributions in Marine Science 27 (suppl.), pp. 641-662.

Solbreck C. \& Sillén-Tullberg B. 1990: Population dynamics of a seed feeding bug, Lygaeus equestris. 1. Habitat patch structure and spatial dynamics. - Oikos 58: 199-209.

SouthwooD T.R.E. 1956: The nomenclature and life-cycle of the European tarnished plant bug, Lygus rugulipennis Poppius (Hem., Miridae). — Bull. Entomol. Res. 46: 845-848.
Southwood T.R.E. 1960: The flight activity of Heteroptera. Trans. R. Entomol. Soc. Lond. 112: 173-220.

Southwood T.R.E. 1962: Migration of terrestrial arthropods in relation to habitat. - Biol. Rev. 37: 171-214.

Southwood T.R.E. 1977: Habitat, the templet for ecological strategies? - J. Anim. Ecol. 46: 337-365.

Southwood T.R.E. 1988a: [This Week's Citation Classic]. Habitat, the templet for ecological strategies? - Current Contents (April 18, 1988): 14.

Southwood T.R.E. 1988b: Tactics, strategies and templets. Oikos 52: 3-18.

SouthwooD T.R.E. 2005: New plant associations of Kleidocerys resadae (Panzer) (Hem., Lygaeidae). — Entomol. Mon. Mag. 141: 138.

Southwood T.R.E. \& Johnson C.G. 1957: Some records of insect flight activity in May, 1954, with particular reference to the massed flight of Coleoptera and Heteroptera from concealing habitats. — Entomol. Mon. Mag. 93: 121-126.

Southwood T.R.E. \& Leston D. 1959: Land and Water Bugs of the British Isles. Wayside and Woodland series. Frederick Warne, London, xi +436 pp.

STEWART R.K. 1968: The biology of Lygus rugulipennis Poppius (Hemiptera: Miridae) in Scotland. - Trans. R. Entomol. Soc. Lond. 120: 437-453.

TAYLOR LR. 1974: Insect migration, flight periodicity and the boundary layer. - J. Anim. Ecol. 43: 225-238.

WALOFF N. 1983: Absence of wing polymorphism in the arboreal, phytophagous species of some taxa of temperate Hemiptera: an hypothesis. - Ecol. Entomol. 8: 229-232.

Wetton M.N. \& Gibson C.W.D. 1987: Grass flowers in the diet of Megaloceraea recticornis (Heteroptera: Miridae): plant structural defences and interspecific competition reviewed. Ecol. Entomol. 12: 451-457.

Wheeler A.G. JR 2001: Biology of the Plant Bugs (Hemiptera: Miridae): Pests, Predators, Opportunists. Cornell University Press, Ithaca, New York, xv +507 pp.

Zera A.J. \& Denno R.F. 1997: Physiology and ecology of dispersal polymorphism in insects. - Annu. Rev. Entomol. 42: 207-231.

Received December 5, 2012; revised and accepted February 28, 2013 